\title{
The 7th Gathering in Biosemiotics - a review
}

\section{Yair Neuman ${ }^{1}$}

In a post-modern era in which the fragmentation of knowledge is evident in every academic field, the attempt to gain a meta-perspective seems like an old anachronistic venture. However, an emerging new field of inquiry seems to challenge this fashionable dogma. Biosemiotics is a field of inquiry that seeks to understand a variety of biological phenomena as sign-mediated processes. For example, to understand biological phenomena, such as immune recognition or genetic coding, as biological processes constituted by signs and their communication.

Biosemiotics is a field with a Janus face. On one hand, it is an antiquarian field which is nurtured by the semiotic tradition of scholars such as Peirce, Uexküll, and Bakhtin. On the other hand, it is a field that seeks to address the challenges of modern biology. In this sense, biosemiotics is deeply rooted in the past but tries to avoid anachronism and irrelevance by addressing current challenges. This is not a simple task since it forces the scholars operating within the biosemiotics community to delicately resonate between old semiotic terminology and current scientific knowledge, and to point to the benefits of conceptualizing biological phenomena from a semiotic perspective. This task is under the continuous threat of falling into obscure jargon and of "name calling". Indeed, if biosemiotics wants to establish its status as a serious field of inquiry it will have to prove the advantages of approaching biological phenomena from a semiotic perspective, and to convince mainstream biology that this advantage exceeds the boundaries of language-games played by a closed group of scholars.

These challenges attracted a group of researchers who participated in the 7th Biosemiotics Gathering. ${ }^{2}$ The gathering took place at the University of

1 Address: Yair Neuman, Office for Interdisciplinary Research, Ben-Gurion University of the Negev, Beer-Sheva, Israel, 84105; e-mail: yneuman@bgu.ac.il.

2 The earlier Gatherings in Biosemiotics took place in Copenhagen (2001, 2003), Tartu (2002), Prague (2004), Urbino (2005), and Salzburg (2006). See also Emmeche 2001; Kull 2002a, 2002b; Witzany, Yip 2007a, 2007 b. 
Groningen under the kind hospitality of Prof. Barend van Heusden from the department of Comparative Literature, from June 6 to June 9, 2007. The participants celebrated the publication of the first book in the new book series dedicated to biosemiotics (published by Springer) and were informed that Springer will launch the new Journal of Biosemiotics under the lead of the editor, Prof. Marcello Barbieri from the University of Ferrara. However, the most important thing in the Gathering was the stimulating presentations and the passionate intellectual discussions that accompanied them. As an interdisciplinary researcher who has participated in many different conferences, I found the Biosemiotics Gatherings to be one of the most intellectually stimulating environments I have ever encountered. These are not conventional social/political conferences of academics that come to show themselves, shake hands with journal editors, to promote their doctoral students or to create alignments with colleagues for getting research grants. The Biosemiotics Gathering was a rare occasion in which scholars who love to think together gather to passionately discuss their ideas. This unique atmosphere is evident in the interdisciplinary nature of the participants. Although the main concern of biosemiotics is with biological systems, the participants extend this basic sense to include in their studies phenomena from other fields to include psychology and literature. Covering in a short academic review all of the presentations is an impossible task and therefore I decided to present some highlights that reflect only my personal taste. While the Biosemiotics Gatherings involve a core of people who regularly participate in the gatherings, I decided to open my presentations' survey with the newcomers.

Victoria N. Alexander, an American scholar and novelist, is a co-founder and director of the Dactyl Foundation for the Arts \& Humanities, in New York City. In her dissertation Alexander has investigated chance and teleology in narrative by writers like Saul Bellow, Henry James, Milan Kundera, Vladimir Nabokov, and C. S. Peirce. In her presentation she discussed the way teleology is associated with emergence and these are associated with poetics. The second newcomer to the gathering was Charles Goodwin, a leading linguist from University of California, Los Angeles, who gave an inspiring talk about the way in which language, human action and cognition constitute situations of activity from girls' play to the work of archeologists. Cognition, as Goodwin suggests, exists in the multiplicities of sign modalities: language, gestures and intonation. The attempt to locate cognition in a wider semiotic context was the subject of another talk by Stephen J. Cowley, a psychologist from the UK. Cowley presented the thesis that infants use semiosis to organize their experience and elaborated on this topic from his recent publications.

Among the "core" biosemioticans, Jesper Hoffmeyer, Claus Emmeche, and Frederik Stjernfelt, all from the University of Copenhagen, gave talks that concerned the meaning of biosemiotics from a wider perspective. Hoffmeyer reemphasized the meaning and importance of biosemiotics; Emmeche, a 
philosopher of science, reflected on biosemiotics and biological sciences from a Kuhnian perspective; and Stjernfelt pointed to the roots of biosemiotics in German thought. Other presentations aimed to point at the alternative biosemiotics may provide to mainstream biology. Marcello Barbieri passionately argued for the relevance of biosemiotics by discussing the evo-devo case and Kalevi Kull, a naturalist and the head of the Semiotics Department at the University of Tartu (Estonia), made the radical statement that biosemiotics can serve as an alternative to (neo)Darwinism.

Some talks discussed more specific applications of biosemitics. Yagmur Denizhan, a professor of Electrical Engineering and a polymath from the University of Bogaziçi (Turkey), presented the case of magnetotactic bacteria as a case study for a biosemiotic description. Marcella Faria, a biochemist from the University of São Paulo (Brazil) examined the non-coding status of some DNA sequences through a biosemiotics perspective and illustrated how this perspective may better explain the role of these structural features in the context of a whole "meaning making" organism. Almo Farina, a landscape ecologist from the University of Urbino (Italy), discussed the "sound-scape" of birds, as a landscape of meaning which is crucial for understanding birds' activity.

What can we learn from this partial list of presentations? The first lesson which is rather trivial is that biosemiotics is still a young interdisciplinary field of inquiry which is seeking its way in the academic world. The second lesson is that biosemiotics is one of the few serious alternatives to mechanical biology. As such, it is a venture worth pursuing.

\section{References}

Emmeche, Claus 2001. The emergence of signs of living feeling: Reverberations from the first Gatherings in Biosemiotics. Sign Systems Studies 29(1): 369-376.

Kull, Kalevi 2002a. Copenhagen, Tartu, world: Gatherings in Biosemiotics 2002. Sign Systems Studies 30(2): 773-775.

- 2002b. Gatherings in Biosemiotics 2. European Communications for Mathematical and Theoretical Biology 4: 26.

Witzany, Günther; Yip, Maricela 2007a. 6. Internationale Biosemiotik-Kongress. Zeitschrift für Semiotik 29(2/3): 294-297.

Witzany, Günther; Yip, Maricela 2007b. Gathering in Biosemiotics 6, Salzburg 2006. Sign Systems Studies 35(1/2). 35(1/2): 295-299. 
